\title{
Állam és tértermelés: „új” értelmezési keretek a tértudományokban
}

\author{
Szerkesztői előszó
}

\section{State and production of space: „new” approaches in spatial sciences}

\section{Editorial}

\author{
TIMÁR JUDIT, NAGY ERIKA
}

TIMÁR Judit: tudományos főmunkatárs, Közgazdaság- és Regionális Tudományi Kutatóközpont, Regionális Kutatások Intézete; 5600 Békéscsaba, Szabó Dezső u. 42.; timar.judit@krtk.mta.hu; https://orcid.org/0000-0002-5275-6905

NAGY Erika: tudományos főmunkatárs, Közgazdaság- és Regionális Tudományi Kutatóközpont, Regionális Kutatások Intézete; 5600 Békéscsaba, Szabó Dezső u. 42.; nagy.erika@krtk.mta.hu; https://orcid.org/0000-0001-9706-4841

KULCSSZAVAK: Henri Lefebvre; tértermelés; társadalmi tér; államkoncepció

ABSZTRAKT: Henri Lefebvre „tértermelésről” szóló elmélete, miközben a Tér és Társadalomban meglehetősen gyorsan visszhangra talált, átfogóbb interpretálására, analitikus keretként történő alkalmazására csak egy évtizede vállalkoznak a magyarországi területi kutatásokban. Ez a tematikus szám e későn indult hazai diskurzus erősítésének szándékával született. Olyan tanulmányokat gyüjt egybe, amelyek szerzői azonos módon gondolkodnak a térről mint társadalmilag termelt folyamatról. Itt közölt írásaik fókuszában egyaránt az állam mint tértermelő szereplő áll. Eredményeik több ponton kapcsolódnak/ kapcsolhatók a térről és az államról, fóként ezek viszonyáról szóló nemzetközi vitákhoz, akár azok lefebvre-i gyökeréig visszanyúlva, és a térkutatások egykor megalkotott elméleti kereteinek mai, magyarországi használatának új lehetőségeit felvillantva.

E bevezető tanulmány első része a lefebvre-i (ill. általában a relacionális) térfelfogásnak azokat a csomópontjait villantja fel, amelyekhez az itt közölt cikkek is kapcsolódnak. Ezek között van a társadalmi tér társadalom által termelt jellegének (valamint ezen összefüggés fordítottjának) elfogadása, a térről való trialektikus gondolkodás, a történelmi materialista megközelítés kérdésfelvetéseit is használó történelmi perspektíva. A tanulmányok fókusza miatt kiemelt szerepet kap maga az a mód, ahogy Lefebvre az államot a tértermeléssel összefüggésben koncepcionalizálja. Ennek az államkoncepciónak a lényegét, majd az ebből kinövő nemzetközi tudományos diskurzusok fontos mozzanatait emeli ki a bevezető további része, és kitér a magyarországi területi kutatások néhány csomópontjára, áramlatára is, amelyekben tetten érhetőek e nemzetközi viták hatásai. Végül, a tematikus szám tanulmányainak azok a lényegi elemei kerülnek kiemelésre, melyek világossá teszik a közös gondolkodás lehetőségeit.

Judit TIMÁR: senior research fellow, Institute for Regional Studies, Centre for Economic and Regional Studies; Szabó Dezső u. 42., H-5600 Békéscsaba, Hungary; timar.judit@krtk.mta.hu; https://orcid.org/0000-0002-5275-6905

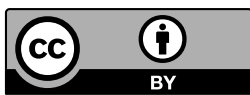


Erika NAGY: senior research fellow, Institute for Regional Studies, Centre for Economic and Regional Studies; Szabó Dezső u. 42., H-5600 Békéscsaba, Hungary; nagye@krtk.mta.hu; https:// orcid.org/0000-0001-9706-4841

KEYWORDS: Henri Lefebvre; production of space; social space; state concepts

ABSTRACT: Henri Lefebvre's critical theory of space and relational thinking about state and space has been slowly making itself felt in academic thought in Hungary since the late 1980s, but has only been widely discussed and recognised as an interpretative-analytical framework for spatial research in the last ten years. By bringing together critical scholars for this special issue, we wanted to contribute to this unfolding academic discourse on the production of space. We also intended to reflect on the state as a social entity that is inherently spatial. Therefore, the contributions collected in this issue share a common focus on certain elements, such as the spatial organisation and practice of the state as well as the assumption that space is socially produced.

In this editorial we emphasize some powerful ideas in Lefebvre's theory of social space and the related international debates which inform the authors, such as the mutually constitutive nature of space and society, the manifestation and reproduction of social relations (and thus, the conditions of the actual mode of production) in, and created through, spatial processes, the conceptualisation of the fluidity of social processes in the dialectics of perceived, conceived and lived space, as well as the spatial nature of social justice. In line with this train of thought, we expound some of Lefebvre's ideas about the state which inspired the debates and critical interpretations of the spatiality of power, its changing technologies, related social practices, and the variegated nature of state spaces in the current system of capitalism. These ideas shaped domestic academic discourse, emerging critical studies and theoretical reflections on the state as an agent and as the structural condition for the production of space in a Hungarian (European, semi-peripheral and transitory) context. By discussing the predominant themes, spatial and scalar foci and approaches in Hungarian spatial research against the backdrop of ",real-world" structural processes and the academic environment described above, we also emphasize the role of spatial studies in deepening our knowledge and in critically depicting state roles in transition, peripherality, European integration and (re-)production of inequalities. Finally, we give an overview of the ideas and key arguments that connect the papers collected in this issue with the core concept of state space in Lefebvre.

Henri Lefebvre-nek, a „tértermelésről” szóló elmélet megalkotójának neve már a Tér és Társadalom első évfolyamának számaiban feltünt (Baráth 1987; Kiss 1987), ha másként nem, egy-egy rövid hivatkozás erejéig. Jelen tematikus szám előkészítése során számunkra mégis meglepő felismerést jelentett, hogy az 1974-ben írt, 1991-ben angolra lefordított, s azóta a tértudományok művelői számára minden bizonnyal egyik legismertebb müről, a „Production of space”-ről (Lefebvre 1991) rendkívül gyorsan, még 1991-ben megjelent („A tér képzése” címmel) egy kiadói katalógus alapján összeállított rövid ismertetés szerkesztői fordításban a TéT-ben. Ez a naprakész reagálás ma azért is hathatott a meglepetés erejével, mert miközben a társadalomtudományokat érintő, többek között épp Lefebvre munkásságára alapozott térfordulatnak (Berger 2018) Magyarországon is felismerhető nyomai voltak, a tértudományokban egy évtizedes kihagyással láttak csak napvilágot a lefebvre-i relacionális térfelfogás legalább rövid interpretációi (pl. Benedek 2000, 2002; Timár 2003; Faragó 2004; Varró 2004). Komolyabb értékeléseket csak a 2010-es évektől olvashatunk (pl. Berki 2012, 2015; Berger 2018; 
Egyed 2018), empirikus kutatások elméleti, elemzési keretéül pedig mind a mai napig kifejezetten ritkán használják (pl. Timár 2006; Berki 2014, 2017a).

Úgy gondoljuk, e későn indult hazai diskurzus erősítésének továbbra is fontos terepe lehet a Tér és Társadalom. E tematikus számban ezért olyan tanulmányokat szedtünk csokorba, melyek szerzői, ha nem is feltétlenül elemzési keretként alkalmazzák a tértermelés elméletét, de valamennyien azonos módon gondolkodnak a térről mint társadalmilag termelt folyamatról. Itt közölt írásaik fókuszában az állam mint tértermelő szereplő áll. ${ }^{1}$ Eredményeik több ponton kapcsolódnak/kapcsolhatók a térről és az államról, fóként ezek viszonyáról szóló nemzetközi vitákhoz, akár azok lefebvre-i gyökeréig is visszanyúlva, és a térkutatások egykor megalkotott elméleti kereteinek mai, magyarországi használatának új lehetőségeit is felvillantják.

A lefebvre-i gondolkodás, illetve általában a relacionális térfelfogás átvételének kiindulópontja a társadalmi tér társadalom által termelt jellegének elfogadása. Amit ebben a nézetben a legtöbb elemző újszerünek tart, az a társadalmi meghatározottság kiemelése mellett a folyamatban való gondolkodás. Neil Smith, azon kevesek egyike, aki már a „Production of space” eredeti francia szövegéhez utat talált, arra is felhívta a figyelmet, hogy „Lefebvre kevésbé a termelési folyamatra, mint inkább a termelés társadalmi viszonyainak újratermelésére fókuszál" (Smith 1990: 90.). Nem véletlen, hogy Lefebvre (1991) a társadalmi teret termelési eszköznek, egyben a kontroll és a hatalom eszközének tartja, ami ezért a társadalom tanulmányozásának is eszköze. Ezek a gondolatok pedig nemcsak a társadalomkutatás föntebb már említett térfordulatához, de a területi kutatások társadalmasításához is elvezettek. Olyan új irányzatokban kaptak fontos szerepet, melyek képviselői erőteljesen kritizálták az abszolút tér koncepcióját, s hozzájárultak ahhoz, hogy a területi kutatások a politikai gazdaságtan mellett számos társadalomelméletet is befogadjanak.

Többek között az ilyen elméletek terjesztéséhez igyekszünk hozzájárulni a magyarországi térkutatásokban a jelen tematikus számmal is, amiben természetesen helyet kap a lefebvre-i koncepció másik gyakran középpontba állított pillére, a térről való trialektikus gondolkodás (Soja 1996) is. A tér megértésének három módja, a térbeli gyakorlatok, a terek reprezentációi és a reprezentáció terei (érzékelt, elgondolt, megélt tér) Lefebvre (1991) interpretációjában egyben a térbeliség komplexitását fejezi ki. A térbeli gyakorlatokat és a terek reprezentációit azonban szerinte nem lineáris értelemben vett dialektikus viszonyban állóknak kell elképzelnünk. Vagyis a reprezentáció terei nem ezek ellentétéből születnek, hanem velük folyamatosan együtt léteznek (Elden 2009). Ez a térfelfogás utat nyitott olyan ellentétpárok destabilizálásához, a dualitásokban gondolkodás kritikáihoz, melyekben fontos érveket fogalmaztak meg pl. a feminista vagy a posztmodern társadalomelméleteket alkalmazó földrajzi irányzatok képviselői. Az abszolút és a relatív, a valós/materiális és az elképzelt/szimbolikus tér szembeállítása mellett a tér és az idő dualizmusa kapott számos bírálatot (Gregory 
2000). Itt csupán az utóbbit érintő, s jelen összeállításunkban is helyet kapott feminista kritikák egyikét kiemelve, Massey $(1992,1994)$ például a mellett teszi le a voksát, hogy a tér csak az idővel integráltan, mint „tér-idő" koncepcionalizálható. Érvelését Lefebvre (1991) tértermelésről alkotott felfogása által is megerősítettnek vélve, egyrészt hangsúlyozza, hogy nemcsak a teret hozzák létre a társadalmi viszonyok és materiális társadalmi gyakorlatok, de a társadalmi is térbelileg konstruált. Márpedig, ha a térbeli szerveződés a társadalom müködésében és változásaiban különbségeket hoz létre, akkor a tér/térbeli nem lehet statikus, történelmen és politikán kívüli. Másrészt a tér/idő dichotómiaként való felfogását azért bírálja, mert az - hasonlóan a férfi-nő szembeállítással - a változás, mozgás, történelem, dinamizmus jellemzőivel leírt időt a privilegizált jelölő pozíciójába helyezi, szemben a mindezek hiányával jellemzett térrel. A feministák dualizmushoz való viszonyával összhangban nem azért emel szót, hogy a „maszkulin” látásmódot egy „femininnel” helyettesítsük, hanem azért, hogy mutassunk rá ennek a gondolkodási módnak a problémáira (Timár 2018).

E tematikus szám néhány szerzője az idő térhez való viszonyának egy másik, Lefebvre (1991) elméletében fellelhető aspektusát ragadja meg. Sokoldalú kritikával alkalmazott marxizmusának egyik megnyilvánulása a térkoncepciójába beépült történelmi materialista megközelítés. Az a megállapítás, hogy a tértermelés az egyes termelési módok által meghatározott sajátosságokat hordoz, talán a mai magyarországi viszonyok között, egy rendszerváltáson túli társadalomban még nagyobb relevanciával bír, mint a nyugati tudományos diskurzusokban, s az itt közölt tanulmányok egy részében is kiemelt szerepet kap.

Végül, Lefebvre olyan elgondolásaihoz való kapcsolódáson túl, mint aminek a tárgya a mindennapi élet vagy a városhoz való jog, ennek a TéT-összeállításnak megkerülhetetlen kérdése maga az a mód, ahogy az államot a tértermeléssel összefüggésben koncepcionalizálja.

Lefebvre államkoncepciója a hatvanas-hetvenes évek pezsgő párizsi baloldali intellektuális közegében, vitáiban formálódott, amelyek - többek között - a korszak politikai rendszereinek, az állam müködtetésükben-fenntartásukban betöltött szerepének szisztematikus kritikáját adták (Gottdiener 1993). Az állam térbeli szerveződésének és „tértermelésben” betöltött akkori szerepének (,state mode of production") megragadásával a kapitalizmus társadalmi viszonyainak, ezek változásainak vizsgálatához állított fel olyan elemzési keretet, amely túlmutatott a korszakon, és ma is vitákat ösztönöz (Brenner, Elden 2009). A lefebvre-i megközelítésben állam és tér elválaszthatatlan. Az állam territoriális szerveződésként (az államhatárokon belüli jogalkotói, -gyakorlói és védelmi szerepben) és hierarchikusan szerveződő intézményei révén (amelyek a fennálló hatalmi viszonyok manifesztációi, ugyanakkor közös normák, értékek hordozói is), a tudomány és a technológia eredményeire támaszkodva megteremti saját racionális „térbeli rendjét”, amelyen keresztül ellenőrzést gyakorol a „kaotikus” magánérdekek vezérelte társadalmi folyamatok és a természet fölött. Ez a rend homogenizál, 
strukturálja társadalmi (-térbeli) gyakorlatainkat/mindennapi életünket, és ezzel (átmenetileg) stabil kereteket biztosít a fennálló viszonyok újratermeléséhez. A kapitalizmus társadalmi viszonyai között az állam szerepe alapvetően a tőkefelhalmozás kereteinek fenntartásában és bővítésében, a tőkésosztály dominanciájának fenntartásában ragadható meg, amihez funkciók, intézmények, helyek hierarchikus térbeli rendjét alakítja ki (Lefebvre 2009). Ennek megértése a társadalmi tér átfogó kritikai koncepcióján keresztül, a teret létrehozó-formáló társadalmi viszonyok, ideológiák, technológiák múködési mechanizmusainak feltárásával lehetséges - túllépve hatalmi struktúrákat fenntartó, az állam által működtetett fragmentált intézményi kereteken és tudáskészleteken (Lefebvre 1991; Brenner, Elden 2009).

Az állam tértermelési folyamat részeként történő megragadása új értelmezések, viták kiindulópontjává vált, amelyek áttekintése túlmutat e bevezető keretein. Ezért az alábbiakban csupán röviden utalunk azokra a csomópontokra és (több ponton is összekapcsolódó) áramlatokra, amelyek a hazai területi kutatásokra - így e tematikus szám szerzőire is - hatottak:

- A kapitalizmus hetvenes években kibontakozó válságának okait, mechanizmusait vizsgáló, alapvetően a városi terek átalakulásából kiinduló kritikai politikai gazdaságtani áramlat az államot (szemben az uralkodó neoklasszikus gazdaságtani értelmezéssel) nem gazdaságon kívüli szereplőként értelmezte. Az új tőkefelhalmozási folyamatok aktív részesének tekintette, amelynek szerepe a termelés (felhalmozás) új térbeli kereteinek kialakításában, a növekedés mind bonyolultabb és költségesebb feltételeinek megteremtésében, a kapitalizmus egyenlőtlenségeket újratermelő térbeli logikájából következő konfliktusok kezelésében ragadható meg (Harvey 1989, 1999; Smith 2011). Az értelmezés túlmutatott a városkutatásokon, és hozzájárult ahhoz, hogy a kibontakozó új (neoliberális-globális) térbeli rend és a változó állami szerepek összekapcsolódó kutatása új vitákat indítson el.

- Többek között ezt a problémát boncolgatta a kilencvenes évek végétől kibontakozó léptékdiskurzus is, amelyben az állam a (társadalmi-) térbeli léptékek közötti hatalmi-intézményi átrendeződések kulcsszereplőjeként jelent meg a területi (és a térbeliség jelentőségét fölismerő más társadalomtudományi) kutatásokban. A viták egyik csomópontja az állam térbeli szerveződésének és (intézményi) gyakorlatainak léptékek/hierarchiák mentén történő értelmezése és annak érvényessége volt. A lépték társadalmi konstrukcióként történő értelmezéséből (Smith 1988) és Jessop (2001), stratégiai-relációs megközelítéséből kiindulva Brenner (2004) a vitát kritikai-strukturalista nézőpontból összegző művében az állam intézményi gyakorlatait („térbeli projektjeit”) alapvetően léptékekhez és lehatárolt terekhez (,territories”) kötődően értelmezte. Ugyanakkor (Lefebvre-re hivatkozva) hangsúlyozta, hogy az állam társadalmi viszo- 
nyokat ellenőrző-alakító szerepe sokkal átfogóbb, különböző tértermelési folyamatokban - így egyes tértermelési folyamatok, pl. a verseny és koncentráció kiegyenlítéssel szembeni dominanciájában - jelenik meg, amelyek lenyomatai az intézményi kereteket és gyakorlatokat formáló stratégiáknak, társadalmi küzdelmeknek. Ezzel az állam térbeli „projektjeinek" eltérő társadalmi-térbeli kontextusaira irányította a figyelmet (Brenner 2004; Brenner et al. 2010), ami az európai (fél)periféria állami tértermelési folyamatainak értelmezésére is hatott (ld. pl. Varró 2010; Pósfai 2018).

- Az állam tértermelő szerepét értelmező viták, illetve a 2008/11-es válság - $\mathrm{s}$ az erre elsősorban nemzetállami keretek között adott válaszok - az intézményi gyakorlatokra, az állam működésére irányították a figyelmet. A vizsgálódások hazai kutatókat is inspiráló kritikai-strukturalista áramlata (amely Lefebvre mellett Foucault-ra is építkezett) a kormányzás (,governance") új technológiáiban - a hagyományos hierarchiák mellett a horizontális szerveződések és a hálózatok növekvő szerepében, külső, elsősorban piaci szereplők politikai döntéseket alakító, növekvő befolyásában, a projektalapú működésben - és ezek egyenlőtlenségeket erősítő következményeiben ragadta meg a neoliberális állam térbeli logikáját (Swyngedouw 2005; Jessop 2010; Peck et al. 2010).

- Az állam térbeli szerveződését és gyakorlatait a szemiotika eszközeivel közelítő kulturális politikai gazdaságtani áramlat a válságokat, az ezekre adott intézményi válaszokat (a struktúrák átrendeződését) és ezek nyelvi folyamatait állította középpontba. Ezzel előtérbe került az állami tértermelés diszkurzív dimenziója is, amellyel egyszerre ragadhatók meg a globális kapitalizmus sokszínűsége mögött húzódó hatalmi viszonyok (pl. a magterületek dominanciája a periféria intézményi gyakorlatai fölött), és értelmezhetők a szociokulturális kontextusokhoz kötődő, eltérő intézményi gyakorlatok, valamint az ezeket formáló társadalmi (hatalmi) mechanizmusok (Jessop, Oosterlynck 2008; Jessop, Sum 2017).

- Ez a megközelítés, továbbá azok az érvelések, amelyek a napi intézményi gyakorlatokra fókuszáltak, és a különböző, lokális terekhez kötődő politikai aktorok stratégiáinak, viszonyának, akcióinak eredőjeként értelmezték az állam működését - megkérdőjelezve pl. a hierarchikus térstruktúrák dominanciáját (Allen, Cochrane 2010) -, az állam térbeli projektjeinek „megélését”, napi társadalmi (térbeli) gyakorlatokba történő beépülését is problematizálták (pl. Rose 1995; Mountz 2004).

Az utóbbi évtizedekben kibontakozó kutatások és viták tehát az állami tértermelés új aspektusainak, illetve totalitásának megragadásával kísérleteztek - amihez többen is Lefebvre eredeti koncepcióját használták kiindulópontként (ld. pl. Brenner et al. 2003; Brenner, Elden 2009). E diskurzusok hatása tetten érhető a hazai területi kutatásokban is, amelyek az államszocializmus lebontása, az Európa keleti felén 
kibontakozó perifériás kapitalizmus és ennek egymást követő válságai, a geopolitikai átrendeződések (uniós csatlakozás, euroatlanti integráció stb.) kontextusában formálódó-változó állami szerepeket és térbeli gyakorlatokat értelmezték. Sajátos fókuszukból következően az állam működésének térbeli aspektusait problematizálták, amivel elmélyítették az átmenettel, a (fél)periféria társadalmi egyenlőtlenségeivel, az európai integrációval kapcsolatos vitákat, koncepciókat.

- Ez megragadható a nemzetállam mint a társadalmi folyamatok domináns - ugyanakkor territorialitásra fókuszált, leegyszerüsítő - értelmezési keretének kritikájában és „lebontásában”. Ez a nézőpont megjelenik a határkutatásokban, amelyek az államhatárt napi gyakorlatok lokális tereiben értelmezik, összekapcsolva ezzel a különböző (társadalmi-térbeli) léptékek szereplőit, folyamatait, ezek változó viszonyrendszereit, történelmi perspektívában értelmezve azokat (pl. Rechnitzer 2005; Hardi et al. 2009; Hajdú 2017). A nemzetállam értelmezési keretként történő „lebontása", illetve nemzetközi lépték-vitákhoz kapcsolása explicit módon is megjelent az utóbbi évek (kritikai) területi kutatásaiban (Berki 2017b; Czirfusz 2017; Nagy 2017).

- A hatalommegosztás térbeli problémaként történő értelmezése a rendszerváltozás óta fontos csomópontja a tudományterületi vitáknak. Utóbbiak a regionalizmus és az átalakuló területi igazgatás gyakorlati kérdései mellett a centralizáció/decentralizáció mechanizmusai, a lokális autonómiák és ezek korlátai, az állam térbeli-hatalmi viszonyokat alakító szerepei köré szerveződtek (pl. Somlyódyné Pfeil 2005; Pálné Kovács 2016a), megvilágítva az intézményi-strukturális (igazgatási) keretek magyarázó erejét a társadalmi-térbeli folyamatok alakításában. A regionalizmus és a területi középszint kérdésköréhez kapcsolódóan bontakozott ki az állam térbeli szerveződésének és gyakorlatainak konstruktivista megközelítése is, amelyben az állam intézményrendszerei és az állami politikák diszkurzív folyamatok és az azok hátterében álló stratégiák, hatalmi viszonyok manifesztációi. Az áramlat a társadalmi tér kritikai koncepciójából kiindulva bírálta a korábbi értelmezések normatív, EU-alapelveket kiindulópontként elfogadó megközelítését. Továbbá az unión belüli és a nemzetállami keretek között zajló diskurzusok, intézményesülési folyamatok, a háttérben húzódó hatalmi küzdelmek eredőjeként értelmezte a hazai területi politikákat és ezek kereteinek alakulását (lásd pl. Faragó 2005; Varró, Faragó 2016). Az európai (fél)periféria folyamataiból kiindulva ugyanakkor az állami tértermelés domináns (pl. kritikai-strukturalista) koncepcióinak kritikája is megjelenik; a kutatók a mellett érvelnek, hogy a gazdaságfókuszú államértelmezéseken túllépve kell feltárni azokat a struktúrákat, viszonyokat, ezek rekurzív-reflexív dialektikáját, amelyek az állam térbeli szerveződését és gyakorlatait formálják az európai „magterületen” kívül (Varró 2010). 
- A lokális terekre (léptékre) fókuszáló vizsgálódások során az állami intézmények gyakorlatainak, az ezeket alakító normáknak a mindennapi élet kereteit alakító szerepét közvetlenül, „testközelben” tapasztalták meg a kutatók; a terepi munka ezért is vált az állami intézményi gyakorlatok és az ezeket alakító normák szisztematikus kritikájának forrásává. Ennek egyik fontos terrénuma a kritikai városkutatás, amelynek tematikájában az állam osztályérdekeket érvényesítő (pl. lakáspolitikák), külső függőségeket közvetítő (pl. financializáció, megszorítások, EU-fejlesztési projektek) politikái/gyakorlatai és ezek térbeli következményei (kiszorítás, szegregáció, polarizáció) kerültek középpontba (pl. Nagy, Timár 2012; Czirfusz et al. 2015; Pósfai, Jelinek 2019). Ugyanakkor a vidékkutatások az állam diszfunkciói (közszolgáltatások, szociálpolitika), a „munkaalapú” társadalomhoz kötődő gyakorlatai, a zsugorodó helyi autonómiák és a vidéki terek polarizációja, gettósodási folyamatai, a helyi és térbeli-hierarchikus (lokális/központi állami) függőségek újratermelődő rendszerei közötti kapcsolatokat tárták fel (pl. Kovács 2010; Virág 2010). Ezek a kutatások egyre több ponton kapcsolódtak a helyi kormányzásra, a hatalommegosztás és autonómia kérdésére, az uniós várospolitikák kritikájára irányuló, közigazgatási fókuszú vizsgálatokhoz is (pl. Keller 2011; Pálné Kovács 2016b), és hatást gyakoroltak más tudományterületek kapcsolódó kutatásaira is (pl. Vastagh 2017).

Az állam térbeli szerveződésének és gyakorlatainak tehát különböző megközelítései, koncepciói, léptékei vannak jelen a hazai területi kutatásokban. A Tér és Társadalom e számával a további vitákhoz szeretnénk hozzájárulni azzal, hogy az itt összegyüjtött tanulmányok a különböző állami szerepeket, tértermelési folyamatokat eltérő térbeli (lépték-) fókusszal, ám vállaltan kritikai nézőpontból értelmezik.

Az itt közölt írások első felében a szerzők valamennyien a városi tér termelését tekintik kutatási tárgyuknak, azonban különböző állami szereplők megismerését, illetve megismertetését helyezik központba. Jelinek Csaba (2019) a magyarországi városrehabilitáció 1970-es évektől máig tartó változásait vizsgálva az állami döntéshozatal különböző léptékeit és intézményeit a globális kapitalizmus folyamataiba ágyazottan tanulmányozza. E mintegy fél évszázados történetben négy korszakot különít el, amivel újat hoz a szocializmus-posztszocializmus kétosztatúságának logikájához képest. A tértermelés kritikai gazdaságtanának a fejlesztési projektek kritikai szociológiájával és antropológiájával párosított elméleti keretezése segítségével jut arra a következtetésre, hogy a magyarországi városrehabilitációk nem tudtak olyan rendszerszerű változást hozni, ami kiküszöböli az egyenlőtlen térbeli fejlődés negatív társadalmi hatásait, sőt, mint azt több eset példázza, érzékelhető szerepük van a marginális terek újratermelésében.

Akárcsak ő, Timár Judit (2019) is tértermelésként értelmezi a városrehabilitációt, a dzsentrifikációt és az ezekhez kapcsolódó társadalmi-térbeli kiszorítást. Éppen ezzel a lefebvre-i megközelítéssel mutat túl tanulmánya annak a győri em- 
pirikus kutatásnak az eredményein, melyben e tértermelési folyamatokat azzal a céllal vizsgálja, hogy az állam és a városrehabilitáció/dzsentrifikáció miatt bekövetkező térbeli kiszorításnak kitett lakók viszonyát megértse. Ennek a megközelítésmódnak köszönhetően tudja a dzsentrifikáció (városrehabilitáció) hatására átalakuló teret a városkutatásokban megszokottól tágabb „tér-időben” vizsgálni, az abban éló korábbi és mai lakók megélt tereit az önkormányzat elgondolt tereivel összevetve tanulmányozni. Timár a mellett érvel, hogy a kiszorítottak és az állam viszonya felől szemlélve - a Győrben is érzékelhető új gazdasági, államszervezési kontextusban - a mai Magyarországon egyfajta „államosított tértermelésről" beszélhetünk.

Nagy Erika és Nagy Gábor (2019) közös tanulmányukban az állam tértermelő szerepét a fogyasztás átalakuló struktúráin és gyakorlatain keresztül vizsgálják, szintén egy győri esettanulmány segítségével. A mellett érvelnek, hogy a városi tereket fizikailag és jelentéstartalmukban/szimbolikusan átformáló projektek (a belváros megújítása, a mega-rendezvények, a posztszocialista átmenet utolsó „szürke” zónáinak felszámolása) új térbeli rend kialakítása irányába mutattak, amelyben tetten érhetők a neoliberális urbanizmus jellemzői, a periféria függőségi viszonyai, és a polgár(i)ság helyi narratívái. Lefebvre társadalmitér-koncepciójából kiindulva ragadják meg a szerzők az „új rend” formálásában kulcsszerepet betöltő helyi állam intézményi gyakorlatait, az ezek hátterében álló mechanizmusokat - a centralizált állami struktúrák és a tőkeérdekek bonyolult hatalmi geometriáját -, ezek helyi autonómiákat meggyengítő hatását.

Sági Mirjam (2019) a nemzetközi kritikai földrajzban „városmilitarizációként” és a „demokratikus közterek hanyatlásaként” koncepcionalizált jelenségeket/folyamatokat vizsgálja magyarországi és budapesti kontextusban, történeti perspektívában. Fókuszában az állam e folyamatok alakításában betöltött szerepe áll, amit alapvetően a közterek állami értelmezésén és használatán keresztül ragad meg. Ehhez részben Lefebvre térértelmezése és Gál (2002) nyilvános és privát közti szemiotikai különbségeket tárgyaló feminista megközelítésü írása nyújt számára elméleti kapaszkodót. Az államszocializmus időszakára visszanyúló, tudományos viták és konkrét politikákba betekintést adó dokumentumok elemzésére épülő eredményei jó alapot adnak a nemzetközi akadémiai diskurzusokba való bekapcsolódásra. Bemutatja azokat a köztérhasználatot szűkítő és bizonyos csoportokat privilegizáló politikákat, amelyek korántsem csak a nyugati, neoliberális viszonyok között, hanem már a szocializmusban is érvényesültek.

A tanulmányok másik csoportja az állam intézményi gyakorlataira - szabályozó-szolgáltató szerepeire (vagy ezek hiányára) - fókuszál, ezeken keresztül vizsgálva a különböző társadalmi csoportokhoz füződő viszonyát. Velkey Gábor (2019) az állam társadalmi reprodukcióban betöltött szerepét, ennek változó intézményi kereteit és társadalmi-térbeli egyenlőtlenségeket fenntartó-újratermelő mechanizmusait boncolgatja tanulmányában. Az intézményi gyakorlatokat, ezek „megélését” és a (mind)ezekre adott válaszokat „alulnézetből”, lokális te- 
rekben végzett kutatásaira építve, a közoktatás állam által ellenőrzött-fenntartott rendszerében elemzi. Ennek kereteit a lefebvre-i térkoncepciónak a közszolgáltatások rendszereire történő adaptációjával; az „elérhető”, a „felkínált” és az „egyszerre ismert és igénybe is vehetö" szolgáltatások körei/terei fogalmak bevezetésével definiálja a szerző. Ebből kiindulva ragadja meg az oktatási rendszerben újratermelődő, s az utóbbi évtized centralizációs mechanizmusai hatására erősödő szelekciós és szegregációs folyamatokat, az ezeket formáló társadalmi viszonyokat - stratégiákat, konfliktusokat, küzdelmeket - különböző, de minden esetben összetett, sokféle problémát hordozó helyi (periférikus-vidéki) kontextusokban.

Mihály Melinda (2019) az állam tértermelési folyamatainak eredményeként is újratermelődő társadalmi-térbeli egyenlőtlenségekre a marginalizálódó vidéki terekben adott válaszokat, a helyi szereplők, illetve az állami szabályozás és intézményi gyakorlatok bonyolult, konfliktusokkal terhelt viszonyát mutatja be tanulmányában. Érvelésében explicit módon a társadalmi tér lefebvre-i és Soja-féle koncepcióját használja értelmezési keretként: a mindennapi élet lokális tereit az ellenállás, a cselekvés, az egyéni és közösségi autonómia forrásának tekinti. Ebből kiindulva ragadja meg a vidéki gettósodás folyamatainak strukturális és „megélt” dimenzióit, elemzi egy helyi közösségi szerveződés ezekre adott válaszait, feltárja a közösségi és egyéni autonómiák ellentmondásos viszonyát, továbbá a lokális, illetve központi állam helyi cselekvést meghatározó (korlátozó-ellenőrző-elbizonytalanító) szerepét.

Kovács András Donát és Farkas Jenő Zsolt (2019) tanulmányában a tértermelés egy formájának, a „tájtermelésnek” a gondolata merül fel. Ebben a közösségi és egyéni érdekek és cselekvések mellett megragadhatónak tartják az állami fejlesztési elképzeléseket és beavatkozásokat, illetve mindezek hatását, ezért az „új környezeti paradigma" (20-21. századi környezettudatos vezérelvek, értékek és cselekvési minták) egyfajta indikátorának is tekintik a szerzők. A tájhasználatban bekövetkező változásokat, a természetvédelem és a mezőgazdaság tájalakító tevékenységének eredményeit fél évszázados távlatban elemzik kvalitatív és kvantitatív módszerekkel kunsági és bácskai mintaterületeken. A vizsgált ágazatok aktorainak értékeléseit is felhasználva, az 1960-as évektől a mezőgazdaság és természetvédelem hat korszakát különítik el. Megállapítják, hogy bár megjelentek a környezettudatos elvek, de az új paradigma megerősödését eltérő társadalmi érdekek akadályozzák, a tájgazdálkodás helyzetében, a tájak állapotában összességében nem történt javulás az elmúlt évtizedekben.

Czirfusz Márton (2019) az állam munkahelyteremtő politikáit, s ezeken keresztül a tőkefelhalmozás kereteit a munkaerő rövid és hosszú távú újratermelésébe történő beavatkozással biztosító szerepét tárgyalja tanulmányában. Az elmúlt évszázad két nagy krízisére fókuszál, történelmi perspektívába helyezve az államnak a piac ciklikus válságaihoz kötődően kiterjesztett szerepét a kapitalizmus tértermelési folyamataiban. Az államot a (kapitalista) társadalmi viszonyok megtestesítőjeként-újratermelőjeként értelmező kritikai felfogásból - a materia- 
lista államelméletből - kiindulva rámutat a munkapiaci beavatkozások egyenlőtlenségeket (újra)termelő mechanizmusaira (intézményi-térbeli szerveződéseire, az ezek keretei között megvalósított térbeli projektekre) és az ezeket alakító hatalmi viszonyokra. Ugyanakkor, túllépve vizsgálatai magyarországi-perifériás kontextusán, a materialista államelmélet magyarázó ereje, így az e tematikus szám keretéül választott állami „,tértermelésnek”, a társadalmi tér kritikai koncepciójának léptékeken átívelő és történelmi perspektívában is értelmezhető érvényessége mellett is érvel.

\section{Jegyzet}

1 A kutatások nagy része s maga ez a bevezető tanulmány is „Az állam strukturális átalakulásaira adott intézményi és egyéni válaszok különböző földrajzi kontextusokban" c. NKFIH (OTKA) K109269 szerződésszámú projekt részeként született a Nemzeti Kutatási, Fejlesztési és Innovációs Hivatal támogatásával.

\section{Irodalom}

Allen, J., Cochrane, A. (2010): Assemblages of State Power: Topological Shifts in the Organization of Government and Politics. Antipode, 5., 1071-1089. https://doi.org/10.1111/j.14678330.2010.00794.x

Baráth E. (1987): Egy térszerkezeti modell. Tér és Társadalom, 3., 23-44. https://doi.org/10.17649/ TET.1.3.3008

Benedek J. (2000): A társadalom térbelisége és térszervezése, RISOPRINT, Kolozsvár

Benedek J. (2002): A földrajz térszemléletének hullámai. Tér és Társadalom, 2, 21-39. https://doi.org/ 10.17649/TET.16.2.847

Berger V. (2018): Térré szôtt társadalmiság. A tér kategóriája a szociológiaelméletekben. L’Harmattan, Budapest

Berki, M. (2012): Post-1990 Urban Brownfield Regeneration in Central and Eastern Europe: A Theoretical Concept. In: Csapó, T., Balogh, A. (eds.): Development of the Settlement Network in the Central European Countries: Past, Present, and Future, Springer Verlag, Berlin, Heidelberg, 137-144.

Berki M. (2014): A városi barnaövezetek funkcióváltása a posztszocialista városokban: Térelméleti megközelítés. In: Dúll A., Izsák É. (szerk.): Tér-rétegek. Tanulmányok a XXI. század térfordulatairól. L'Harmattan, Budapest, 120-133.

Berki M. (2015): A térbeliség trialektikája. Tér és Társadalom, 2., 3-18. https://doi.org/10.17649/TET. 29.2.2658

Berki M. (2017a): Érzékelt tér, elgondolt tér, megélt tér: A térbeliség trialektikája egy budapesti barnamező-rehabilitációs beruházás példáján. Tér és Társadalom, 2., 23-43. https://doi.org/ 10.17649/TET.31.2.2844

Berki M. (2017b): A földrajzi lépték változó értelmezése és a cselekvőhálózat-elmélet. Földrajzi Közlemények, 3., 203-215.

Brenner, N. (2004): New State Spaces. Oxford University Press, Oxford.

Brenner, N., Elden, S: (2009): Henri Lefebvre on State, Space, Territory. International Political Sociology, 3., 353-377. https://doi.org/10.1111/j.1749-5687.2009.00081.x 
Brenner, N., Jessop, B., Jones, M., Macleod, G. (2003): State Space in Question. In: Brenner, N., Jessop, B., Jones, M., Macleod, G. (eds.): State/Space: A Reader. Blackwell, Oxford, 1-26.

Brenner, N., Peck, J., Theodore, N. (2010): Variegated neoliberalization: geographies, modalities, pathways. Global Networks, 2., 182-222. https://doi.org/10.1111/j.1471-0374.2009.00277.x

Czirfusz M. (2017): A gazdaságföldrajz elméletei a térről és a gazdaságról. Földrajzi Közlemények, 3., 192-202.

Czirfusz, M. (2019): Munkanélküliség és az állam tértermelése Magyarországon két válságidőszakban. Tér és Társadalom, 4, 177-196. https://doi.org/10.17649/TET.33.4.3170

Czirfusz, M., Horváth, V., Jelinek, Cs., Pósfai, Zs., Szabó, L. (2015): Gentrification and Rescaling Urban Governance in Budapest-Józsefváros. Intersections, 4., 55-77. https://doi.org/10.17356/ ieejsp.v1i4.104

Egyed I. (2018): A tértermelés neomarxista kritikája: a technokrata térreprezentációktól a lefebvre-i városhoz való jog instrumentalizációjáig. In Faragó L. (szerk.): Kortárs térelméletek kelet-közép európai kontextusban. Dialóg Campus, Budapest, Pécs, 165-185.

Elden, S. (2009): Production of space. In: Gregory, D., Johnston, R.J., Pratt, G., Watts, M., Whatmore, S. (eds.): The Dictionary of Human Geography. 5th Edition. Wiley-Blackwell, Malden, MA, 590-592.

Faragó L. (2004): A regionalizmus hajtóerői Magyarországon. Tér és Társadalom, 3., 1-23. https:// doi.org/10.17649/TET.18.3.955

Faragó, L. (2005): The driving forces of regionalism in Hungary. In: Timár, J., Barta, Gy., G. Fekete, É., Szörényiné Kukorelli, I. (eds.): Hungarian spaces and places: Patterns of transition. MTA RKK, Pécs, 73-91.

Gal, S. (2002): A Semiotics of the Public/Private Distinction. Difference: A Journal of Feminist Cultural Studies, 1., Spring, 77-95.

Gottdiener, M. (1993): The Marx of our time: Henri Lefebvre and the production of space. Sociological Theory, 1., 129-134.

Gregory, D. (2000): Space, human geography and. In: Johnston, R. J., Gregory, D., Pratt, G., Watts, M. (eds.): The Dictionary of Human Geography. 4th Edition. Wiley-Blackwell, Malden, MA, 767-773.

Hajdú Z. (2017): Állam vagy/és ország: Fogalmi és területi ütközések a Kárpát-medencében. Történeti Földrajzi Közlemények, 3-4., 1-21.

Hardi, T., Hajdú, Z., Mezei, I. (2009): Határok és városok a Kárpát-medencében. MTA RKK, Győr, Pécs

Harvey, D. (1989): The condition of postmodernity. Blackwell, Oxford

Harvey, D. (1999): The limits of capital. Verso, London

Jelinek Cs. (2019): A városrehabilitáció korszakai Magyarországon: Az állam szerepe marginális városi terek (újra)termelésében. Tér és Társadalom, 4., 17-37. https://doi.org/10.17649/TET. 33.4.3180

Jessop, B. (2001): Insitutional re(turns) and the strategic-relational approach. Environment and Planning A, 7., 1213-1235. https://doi.org/10.1068/a32183

Jessop, B. (2010): The „return” of the national-state in the current crisis of the world market. Capital and Class, 1., 38-43.

Jessop, B., Oosterlynck, S. (2008): Cultural political economy: On making the cultural turn without falling into soft economic sociology. Geoforum, 3., 1155-1169. https://doi.org/10.1016/j.

Jessop, B., Sum, N. (2017): Putting the 'Amsterdam School' in its Rightful Place: A Reply to Juan Ignacio Staricco's Critique of Cultural Political Economy. New Political Economy, 3., 342-354.

Keller J. (2011): Heterarchia és fejlődési pályaváltás. Új elméleti megközelítés a kistérségkutatásban. Tér és Társadalom, 3., 3-26. https://doi.org/10.17649/TET.25.3.1877

Kiss R. (1987): „Milyen várost, milyen teret? Manuel Castells és a francia városszociológia néhány aspektusa. Tér és Társadalom, 4., 103-109. thhps://doi.org/10.17649/TET.1.4.48

Kovács A. D., Farkas J. Zs. (2019): Tájváltozások társadalmi hátterének vizsgálata alföldi példákon. Tér és Társadalom, 4., 157-176. https://doi.org/10.17649/TET.33.4.3169

Kovács K. (2010): Vidéki változások a rendszerváltás után. In: Barta Gy., Beluszky P., Földi Zs., Kovács K. (szerk.): A területi kutatások csomópontjai. MTA RKK, Pécs, 73-104.

Lefebvre, H. (1991 [1974]): The Production of Space. Trans. Nicholso-Smith, D. Blackwell, Oxford, Cambridge, MA

Lefebvre, H. (2009): State, Space, World: Selected Essays (edited by Brenner, N; Elden, S.). Minnesota Press, Minneapolis 
Massey, D. (1992): Politics and space/time. New Left Review, 196., 65-84.

Massey, D. (1994): Space, Place and Gender. Polity Press, Cambridge

Mihály M. (2019): Újratermelődo” „gettók”? - A helyi fejlesztés lehetőségei és korlátai egy szélsőségesen marginalizált kistelepülésen. Tér és Társadalom, 4., 132-156. https://doi.org/10.17649/ TET.33.4.3179

Mountz, A. (2004): Embodying the nation-state: Canada's response to human smuggling. Political Geography, 3., 323-345. https://doi.org/10.1016/j.polgeo.2003.12.017

Nagy E. (2017): Az állam változó szerepe - gazdaságföldrajzi értelmezések. Földrajzi Közlemények, 3., 226-234.

Nagy E., Nagy G. (2019): Az állam szerepe a városi terek fogyasztásközpontú „újratermelésében”. Tér és Társadalom, 4., 61-86. https://doi.org/10.17649/TET.33.4.3192

Nagy, E., Timár, J. (2012): Urban restructuring in the grip of capital and politics: Gentrification in East-Central Europe. In: Csapó, T., Balogh, A. (eds.): Development of the Settlement Network in the Central European Countries: Past, Present, and Future. Springer Verlag, Berlin, Heidelberg, 121-135.

Pálné Kovács I. (2016a): Modellváltás a magyar önkormányzati rendszerben. In: Jakab, A., Gajduschek, Gy. (szerk.): A magyar jogrendszer állapota. MTA Társadalomtudományi Kutatóközpont, Jogtudományi Intézet, Budapest, 583-599.

Pálné Kovács I. (szerk.) (2016b): A magyar decentralizáció kudarca nyomában. Dialóg Campus Kiadó, Budapest, Pécs

Peck, J., Brenner, N., Theodore, N. (2010): Postneoliberalism and its malcontents. Antipode, 1., 94-116. https://doi.org/10.1111/j.1467-8330.2009.00718.x.

Pósfai, Zs. (2018): Reproducing uneven development on the Hungarian housing market. PhD dissertation. http://doktori.bibl.u-szeged.hu/9753/

Pósfai, Zs., Jelinek Cs. (2019): Reproducing Socio-Spatial Unevenness through the Institutional Logic of Dual Housing Policies in Hungary. In: Lang, T., Goermar, F. (eds): Regional and Local Development in Times of Polarisation. Palgrave Macmillan, London, 197-223.

Rechnitzer, J. (2005): Az osztrák-magyar határmenti együttműködés múltja, jelene, jövője. Tér és Társadalom, 2., 7-29. https://doi.org/10.17649/TET.19.2.997

Rose, G. (1995): Geography and gender, cartographies and corporealities. Progress in Human Geography, 4., 544-548. https://journals.sagepub.com/doi/10.1177/030913259501900407

Sági M. (2019): Az állam szerepe a „közterek hanyatlásában” - történelmi perspektívában. Tér és Társadalom, 4., 87-103. https://doi.org/10.17649/TET.33.4.3202

Smith, N (1988): Regional adjustment or restructuring? Urban Geography, 3., 318-324. https://doi.org/ 10.2747/0272-3638.9.3.318

Smith, N. (1990 [1984]): Uneven development. Nature, capital and the production of space. Second edition. Basil Blackwell, Cambridge

Smith, N. (2011): Uneven development redux. New Political Economy, 2., 261-265. https://doi.org/ 10.1080/13563467.2011.542804

Soja, E. (1996): Thirdspace. Journeys to Los Angeles and other real-and-imagined places. Blackwell, Oxford.

Somlyódyné Pfeil, E. (2005): Balancing between transition and modernity: Principles and institutions of regional planning in Hungary. In: Timár, J., Barta, Gy., G. Fekete, É., Szörényiné Kukorelli I. (eds.): Hungarian spaces and places: Patterns of transition. MTA RKK, Pécs, 106-123.

Swyngedouw, E. (2005): Governance innovation and the citizen: The Janus-face of governancebeyond-the-state. Urban Studies, 11., 1991-2006. https://doi.org/10.1080/00420980500279869

Timár J. (2003): Problémák és perspektívák: „Mi a teendő” a kialakulóban lévő kritikai geográfia számára Magyarországon? Tér és Társadalom, 2., 53-65. https://doi.org/10.17649/TET.17.2.891

Timár J. (2006): Az agglomerálódástól a szuburbanizációig: „Tértermelés” a posztszocialista Magyarországon. In: Csapó T., Kocsis Zs. (szerk.): Agglomerációk és szuburbanizálódás Magyarországon: Településtudományi konferencia. Savaria University Press, Szombathely, 35-51.

Timár J. (2018): A feminista és a marxista földrajz kapcsolata: összekötő és elválasztó diskurzusok a térről. In: Faragó L. (szerk.) Kortárs térelméletek kelet-közép-európai kontextusban. Dialóg Campus Kiadó, Budapest, 187-203.

Timár J. (2019): „Államosított tértermelés” a kiszorítottak perspektívájából egy dzsentrifikálódó 
városrészben. Tér és Társadalom, 4., 38-60. https://doi.org/10.17649/TET.33.4.3204

Varró K. (2004): A régió mint diszkurzív termék. Tér és Társadalom, 1., 73-91. https:/doi.org/10.17649/ TET.18.1.932

Varró, K. (2010): Re-Politicising the Analysis of „New State Spaces” in Hungary and beyond: Towards an Effective Engagement with "Actually Existing Neoliberalism”. Antipode, 5., 1253-1278. https://doi.org/10.1111/j.1467-8330.2010.00801.x

Varró, K., Faragó, L. (2016): The Politics of Spatial Policy and Governance in post-1990 Hungary: The Interplay between European and National Discourses of Space. European Planning Studies, 1., 39-60. https://doi.org/10.1080/09654313.2015.1066760

Vastagh Z. (2017): Társadalmi struktúra és állami redisztribúció. Napvilág Kiadó, Budapest

Velkey G. (2019): A társadalmi-térbeli egyenlőtlenségek és újratermelésük a hazai alapfokú oktatási rendszerben. Tér és Társadalom, 4, 104-130. https://doi.org/10.17649/TET.33.4.3191

Virág T. (2010): Kirekesztve: falusi gettók az ország peremén. Akadémiai Kiadó, Budapest 